\title{
Preference Shifts, Structural Breaks and the Domestic Demand for Chilean Wine
}

Cristián Troncoso-Valverde ${ }^{1}$

\begin{abstract}
This paper investigates possible changes in Chilean domestic consumer preferences for wine through the estimation of a demand function that allows for structural breaks and regime shifts in the cointegrating relationship. Our findings support both higher own-price elasticity and higher substitutability between wine and beer after 1982, when a shift in regime in the demand function is found. We believe our findings might be due to the introduction of an increasing number of wine varieties in Chile during the last two decades. We argue that more wine varieties affect domestic consumer preferences by altering the product diversity available in the domestic market.
\end{abstract}

Keywords: Preference shifts, wine demand, structural breaks, product diversity.

JEL Classification: D11, C22, Q11.

\footnotetext{
${ }^{1}$ Lecturer in Economics of the University of TALCA. Correspondence address: Facultad de Ciencias Empresariales, Universidad de Talca, 2 Norte 685, Casilla 721, Talca, Chile. E-mail: ctroncos@utalca.cl. I would like to thank the members of the Department of Economics at Concordia University, Montreal, Canada, where part of this research was carried out. I would also like to thank Ereney Hadjigeorgalis, Pablo Morán and two anonimous refeeres for their valuable comments and suggestions.
} 
Resumen - El presente artículo investiga posibles cambios en las preferencias de los consumidores chilenos de vino por medio de la estimación de una función de demanda que permite quiebres estructurales y cambios de régimen en el vector de cointegración de la misma. Nuestros resultados muestran una alta elasticidad - precio y una mayor sustitución entre vino y cerveza a partir de 1982, fecha en la cual un cambio de régimen en la función de demanda es detectado. Dichos resultados pueden ser atribuidos a la introducción de un creciente número de variedades de vino en Chile en las últimas dos décadas. Así, la introducción de un mayor número de variedades de vino afecta las preferencias de los consumidores chilenos al alterar la variedad de productos disponibles en el mercado chileno de vino.

Palabras claves: Cambio en preferencias, demanda por vino, quiebres estructurales, variedad de productos, cointegración.

Clasificación JEL: D11, C22, Q11.

Resumo - Este artigo investiga possíveis mudanças nas preferências dos consumidores de vinho por meio da estimação de uma função da demanda que permite a ruptura estrutural e a mudança do regime no vetor da co-integração do mesmo. Nossos resultados mostram uma elevada elasticidade - preço e uma maior substituição entre o vinho e a cerveja a partir de 1982, data na qual uma mudança do regime na função da demanda é detectada. Estes resultados podem ser atribuídos à introdução de um número crescente das variedades do vinho no Chile nas últimas duas décadas. Assim, a introdução de um maior número de variedades do vinho afetará as preferências dos consumidores chilenos ao alterar a variedade dos produtos disponíveis no mercado de vinho chileno.

Palavras-chave: Deslocamentos da preferência, demanda do vinho, rupturas estruturais, diversidade do produto, co-integração.

Classificacão JEL: D11, C22, Q11. 


\section{Introduction}

During the last two decades, the Chilean wine industry has experienced a strong and accelerated process of internationalization. Investments in new production technologies, more qualified human capital and improved marketing processes are among the main reasons that explain the observed growth rates of $41 \%$ in wine production and $834 \%$ in wine exports during the 1990-2000 period. Notwithstanding, this industry has also been affected by the global decline in per-capita wine consumption. In fact, Chilean per capita wine consumption has fallen from 68 liters in 1962 to 18 liters in 2001. According to many authors [Anderson et al. (2002); Schnettler and Rivera (2003); Costa (2001) and cites therein], there has been a strong tendency to substitute wine for other type of alcoholic beverages, mainly beer, during the last two decades. This substitution effect is, in opinion of these authors, the result of a change in consumer's tastes. However, up to the author's knowledge, no formal attempt to empirically assess the validity of this claim has been performed.

The domestic Chilean wine market has been the subject of several studies [Mujica and Celedon (1982); Oncken (1983); Mujica and Oncken (1984); Cremaschi (1991); Martinez (1995)]. These studies have focused on the magnitude of elasticity estimates and the conduction of statistical inference over these estimates. For instance, Mujica and Celedon (1982) and Oncken (1983) use their demand elasticity estimates for evaluating the effect of a potential tax cut over wine consumption and tax evasion. Others, such as Martinez (1995), focus their research on estimation and hypothesis testing. Overall, the findings of all these studies reveal conflicting evidence about domestic wine demand elasticities. While authors like Mujica and Celedon (1982) claim that domestic wine demand is very price-inelastic, Mujica and Oncken (1984) and Martinez (1995) argue that price - elasticity should be close to one. There is a similar disagreement in what regards the income elasticity estimates. In addition, all the aforementioned papers have either discarded price of beer as an 'explanatory' variable in wine demand specification or been unable to find evidence supporting the relevance of beer as a substitute for wine. This result appears unsatisfactory since, from a theoretical 
point of view, beer should be considered as substitute of wine. Moreover, from an empirical point of view, this result appears in contradiction with the observed pattern of wine and beer consumption during the last two decades in Chile.

Table 1. Wine and beer consumption in Chile

\begin{tabular}{cccccc}
\hline Year & $\begin{array}{c}\text { Wine } \\
\text { (Liters) }\end{array}$ & $\begin{array}{c}\text { Beer } \\
\text { (Liters) }\end{array}$ & Year & $\begin{array}{c}\text { Wine } \\
\text { (Liters) }\end{array}$ & $\begin{array}{c}\text { Beer } \\
\text { (Liters) }\end{array}$ \\
\hline 1971 & 51.90 & 9.00 & 1986 & 36.00 & 20.80 \\
1972 & 59.00 & 11.00 & 1987 & 32.00 & 21.28 \\
1973 & 53.50 & 9.00 & 1988 & 30.00 & 21.83 \\
1974 & 45.90 & 11.00 & 1989 & 28.00 & 21.19 \\
1975 & 41.90 & 12.00 & 1990 & 26.00 & 20.26 \\
1976 & 45.10 & 13.00 & 1991 & 23.00 & 21.25 \\
1977 & 49.20 & 14.00 & 1992 & 18.00 & 26.90 \\
1978 & 45.40 & 14.66 & 1993 & 13.00 & 28.86 \\
1979 & 44.10 & 16.47 & 1994 & 18.00 & 27.81 \\
1980 & 42.70 & 17.08 & 1995 & 15.00 & 28.50 \\
1981 & 41.70 & 15.88 & 1996 & 15.80 & 27.72 \\
1982 & 40.10 & 15.31 & 1997 & 13.10 & 27.54 \\
1983 & 38.80 & 15.26 & 1998 & 18.30 & 27.43 \\
1984 & 37.50 & 15.96 & 1999 & 17.00 & 26.05 \\
1985 & 36.90 & 17.02 & 2000 & 17.80 & 26.62 \\
\hline
\end{tabular}

Data on wine consumption were obtained from the Department of Alcoholic Beverages, S.A.G., Chilean Ministry of Agriculture. Beer consumption data were obtained from Pavez (2002). All data are in per capita terms.

As Table 1 shows, per-capita wine consumption has strongly declined during the last two decades, whereas per-capita beer consumption has shown an increase in consumption. This apparent substitution between beer and wine may be viewed as either the consequence of an autonomous shift in consumers' preferences ${ }^{2}$ or the consequence of the introduction of more varieties of wine in the Chilean domestic market. Until 1979, there were severe regulations affecting both production and consumption of wine in Chile. For instance, only a maximum of 60 liters per capita of wine production per winery was permitted and high specific taxes over production and consumption were applied (Mujica and Celedon, 1982). In 1979, several of these restriction were either eliminated or relaxed causing an increase of wine production during the following years. Likewise, by the end of the seventies the Chilean wine

${ }^{2}$ For a detailed discussion on autonomous preference shifts, see Butter et al. (1997). 
industry began to undertake important investments in new production technologies, which contributed to further increase the production of wine (Martinez, 1995). The increase in wine production together with the decline in domestic wine consumption resulted in a domestic demand being unable to absorb all the wine production. This triggered a deep transformation of the industry as a whole, changing its focus toward the production of more competitive premium wine varieties. This, in turn, was done with the aim of reaching foreign markets. However, given the fact that the wine being supplied to the domestic market at that time (mainly Cabernet Sauvignon and Sauvignon Blanc) was not of the taste of foreign consumers, local producers gradually shifted to varieties such as Merlot, Chardonay, Carmenère and Syrah (Banda, 2002). As a consequence of this, new types of wines began to be available in the domestic market. In fact, domestic wine consumption began to show some signs of recovery by the middle of the nineties, with per capita consumption stabilizing around 17 liters per year. Although this quantity is far from the 60 liters per capita in the sixties, current wine consumption is associated with wine of better quality [c.f. CORFO (1998); Costa (2001); Schnettler and Rivera (2003); Banda (2002)]. Thus, the introduction of new varieties of wines altered the bundle of wines available for domestic consumers. Hence, if consumers value product diversity, this broader variety of wines might have induced the observed substitution pattern (or part of it) shown in Table 1.

The purpose of this paper is to empirically investigate potential changes in domestic consumer tastes for wine through the estimation of a domestic wine demand model that allows for structural breaks and regime shifts. The estimation is carried out employing time-series techniques that account for possible nonstationarity in the model variables. To examine possible regime shifts in the demand function, we apply the Gregory and Hansen (1996) and Bai and Perron (1998) methodologies for the analysis of structural breaks in the cointegrating relationships and the Hansen (1992) technique to test for parameter instability.

The rest of the paper is organized as follows. Next section describes the econometric methodology we use throughout as well as the data employed in this study. Section 3 presents the main results and section 4 ends the paper with some conclusions and final remarks. 


\section{Methodology and Data}

The econometric methodology that we use throughout is primarily concerned with the estimation of lineal models in the presence of non-stationary variables and structural breaks in the cointegrating vector. When variables are non-stationary, serious bias in conventional tests may arise because the distributions of traditional statistics (such as the $\mathrm{t}-$ or the F-statistic) diverge completely under nonstationarity from those derived under stationarity (Phillips, 1986). Similarly, parameter estimates may suffer from serious bias when nonstationarity is disregarded in the estimation stage. An elegant way to proceed when variables are nonstationary is to look for cointegration among them (Engle and Granger, 1987). Thus, even if model variables are nonstationary, there may still exist a linear combination of them that forms a stationary stochastic process. This linear combination (known as cointegrating vector) is often thought of as describing a long-run relationship among the variables ${ }^{3}$.

The model under study in this paper is the following

$$
q_{t}=\beta_{0}+\beta_{1} p_{t}+\beta_{2} p s_{t}+\beta_{3} y_{t}
$$

where $q_{t}$ is domestic per capita wine consumption, $p_{t}$ is the real price of wine, $p s_{t}$ is real price of beer and $y_{t}$ is real per capita GDP. All variables are taken in logarithms. Two comments are in order at this point. First, in light of our previous discussion, the inclusion of the price of beer as one of the 'explanatory' variables in (2.1) may seem surprising. However, we conjecture that the lack of significance found in previous studies is mainly due to nonstationarity. Second, the demand equation (2.1) may appear misspecified since no variable accounting for imports of wine is included. However, imports do not represent an important component of wine consumption in Chile (no more than $2 \%$ of total consumption and just $0,95 \%$ in $2002^{4}$ ). Thus, we disregard wine imports as a regressor of domestic wine demand given the expected little effect over Chilean domestic demand for wine.

\footnotetext{
${ }^{3}$ For a well detailed exposition about cointegration analysis, see Hendry and Juselius (2000a) and Hendry and Juselius (2000b).

${ }^{4}$ Corporación Chilena del Vino (Chilean Wine Association) and Central Bank of Chile.
} 
Parameters in model (2.1) will be estimated using the Fully Modified (FM) single-equation method of Phillips and Hansen (1990). The FM technique is designed to estimate cointegrating relations directly by modifying traditional OLS estimation with non parametric corrections that take into account serial correlation caused by unit roots, and system endogeneity caused by cointegration. Furthermore, Phillips (1995) has shown that the FM estimation technique yields t-statistics for parameter estimates which have a normal limiting distribution even in the presence of cointegrated explanatory variables. Thus, standard inferential techniques can be used to test hypothesis on the parameter estimated through the FM technique.

To address the issue of structural breaks and parameter stability we apply the econometric methodology proposed by Hansen (1992) and Gregory and Hansen (1996). The latter technique allows us not only to empirically investigate parameter instability but also to endogenously obtain an estimate of the break point that can be used to re-estimated the model. Since we do not want to restrict a priori the existence of multiple structural breaks in the demand function, we follow Bai and Perron (1998) methodology (henceforth the BP methodology) as suggested by Morales and Peruga (2002). The BP methodology consists in estimating unknown regression coefficients (by OLS) together with the break points using the information contained in the entire sample. This is clearly an advantage over other multiple structural break techniques since the estimation of the break points requires of at most least squares operations of order $\mathrm{O}\left(\mathrm{T}^{2}\right)$, while a standard grid search procedure (such as the one used by Gregory and Hansen (1996)) would require least squares operations of order $\mathrm{O}\left(\mathrm{T}^{\mathrm{m}}\right)$, $m$ being the maximum number of breaks allowed in the sample (Bai and Perron, 2001). Although the BP methodology was developed for stationary regressors, Morales and Peruga (2002) show that the break point estimated by this methodology is consistent even if regressors are nonstationary. Hence, we view the BP methodology as a complementary technique to the instability tests of Hansen (1992) and Gregory and Hansen (1996).

If we find evidence of one structural break, the following 'two regime model' will be estimated:

$q_{t}=\beta_{0}+\beta_{1} p_{t}+\beta_{2} p s_{t}+\beta_{3} y_{t}+\beta_{4} D U_{t}+\beta_{5} p_{t} D U_{t}+\beta_{6} p s_{t} D U_{t}+\beta_{7} y_{t} D U_{t}+\mathrm{v}$ 
where $D U_{t}=1(t \geq \hat{t}), 1($.$) is the indicator function, \hat{t}$ is the estimated time of the break and $v$ is a $I(0)$ process. In case that evidence of multiple structural breaks is found, we re-estimate model (2.1) adding a dummy variable for each break that is found. The fact that we accommodate multiple breaks with dummy variables obeys to the small sample size we are working with. To model each of these breaks as a regime shift would leave us with too few degrees of freedom for parameter estimation.

The data set covers the 1949-1998 period and has been obtained from the Instituto Nacional de Estadísticas (INE) ${ }^{5}$, Chilean Ministry of Agriculture $^{6}$ and the Central Bank of Chile. All prices are in real terms. We use two price deflators: the Consumer Price Index (IPC), published by the INE, and the implicit GDP deflactor, published by the Central Bank of Chile. A more detailed description of the variables used in this study can be found in Appendix 1.

\section{Empirical Analysis}

The integration order of each model series is investigated by applying two types of unit-root tests ${ }^{7}$. The first type of tests corresponds to the $M$ class of unit-root tests suggested by Ng and Perron (2001). The second type of tests consists of unit-root tests that assume as the alternative hypothesis a stationary series that fluctuates around a deterministic function with a broken trend [Zivot and Andrews (1992); Vogelsang and Perron (1998) and Lee and Strazicich (2001)]. The results are reported in Table 2 and Table $3^{8}$.

${ }^{5}$ Chilean Statistical Bureau.

${ }^{6}$ Data were obtained from the Servicio Agrícola y Ganadero, SAG. Ministerio de Agricultura, Chile.

${ }^{7}$ For a more extensive survey on unit-root tests and univariate time-series analysis, see Hendry and Juselius (2000a).

${ }^{8}$ All tests were conducted using GAUSS 3.6.17. The GAUSS codes are available upon author's request. 
Table 2. $M$ class of unit-root tests

\begin{tabular}{|c|c|c|c|c|}
\hline Tests & $q_{t}$ & $p_{t}$ & $p s_{t}$ & $y_{t}$ \\
\hline Phillips-Perron $\mathrm{Z} \alpha$ & -8.456 & -13.578 & -12.625 & -2.714 \\
\hline Modified Phillips-Perron MZ $\alpha$ & -7.373 & -11.539 & -10.739 & -2.560 \\
\hline Modified Phillips-Perron MZ $\alpha$ & -1.882 & -2.382 & -2.296 & -0.833 \\
\hline $\mathrm{ADF}^{\mathrm{GLS}}$ & -2.159 & -2.803 & -2.700 & -0.883 \\
\hline
\end{tabular}

These unit-root test correspond to those suggested by Ng and Perron (2001). Asymptotic critical values for the MZ $\alpha, M Z \alpha$ and the ADF ${ }^{\mathrm{GLS}}$ tests can be found in Table I of Ng and Perron (2001, p. 1524). Critical values for the Phillips-Perron Z $\alpha$ test can be obtained from MacKinnon (1996)

Table 3. Unit-root tests with broken trend.

\begin{tabular}{|c|c|c|c|c|c|c|c|c|c|}
\hline \multirow[t]{2}{*}{ Series } & \multicolumn{2}{|c|}{ ZA Min $\operatorname{t} \alpha$} & \multicolumn{2}{|c|}{ IO Min $t \alpha$} & \multicolumn{3}{|c|}{ AO Min $t \alpha$} & \multicolumn{2}{|c|}{ Min LM test } \\
\hline & $\begin{array}{c}\text { Model } \\
\text { A }\end{array}$ & $\begin{array}{c}\text { Model } \\
\text { B }\end{array}$ & $\begin{array}{c}\text { Model } \\
\text { A }\end{array}$ & $\begin{array}{c}\text { Model } \\
\text { C }\end{array}$ & $\begin{array}{c}\text { Model } \\
\text { A }\end{array}$ & $\begin{array}{c}\text { Model } \\
\text { B }\end{array}$ & $\begin{array}{c}\text { Model } \\
\text { C }\end{array}$ & $\begin{array}{c}\text { Model } \\
\text { A }\end{array}$ & $\begin{array}{c}\text { Model } \\
\text { B }\end{array}$ \\
\hline$q_{t}$ & -2.94 & $-4.63 * *$ & -3.32 & -4.80 & -3.05 & $-4.47^{* *}$ & -4.56 & -2.33 & -3.41 \\
\hline$p_{t}$ & -4.19 & $-4.42 * *$ & -4.90 & -4.94 & -4.52 & $-4.16^{* *}$ & -4.89 & $-4.38 * *$ & $-4.48^{*}$ \\
\hline$p s_{t}$ & -3.93 & $-6.66 * * *$ & $-6.53 * * *$ & $-8.16 * * *$ & $-6.47 * * *$ & $-4.60 * *$ & $-7.04 * * *$ & $-4.86^{* *}$ & $-7.83 * * *$ \\
\hline$y_{t}$ & -2.94 & $-4.93 * * *$ & -3.13 & -5.06 & -2.12 & -2.79 & -2.95 & -1.74 & -3.99 \\
\hline
\end{tabular}

These unit-root tests correspond to the Min ta of Zivot and Andrews (1992); the Min t $\alpha$ for innovational (IO) and additive models (AO) of Vogelsang and Perron (1998); and the Min LM test of Lee and Strazicich (1999). Critical values can be found at these papers. Model A corresponds to the 'crash model'; Model B to the 'changing growth model' and Model C to the 'crash/changing model', as defined in Vogelsang and Perron (1998). $\left({ }^{* *}\right),(* *),(*)$ means significance at 1,5 and $10 \%$.

From the results presented in Tables 2 and 3, we can conclude that the null of a unit root for almost all individual series can not be rejected at any conventional significance levels. The only exception is the price of beer series for which evidence is not conclusive. However, there are clear indications that nonstationarity is an important property of our series. More precisely, evidence reported in Table 2 and Table 3 appears to support integration of order one for all model series.

As mentioned in the previous section, model (2.1) was estimated using the FM single-equation technique of Phillips and Hansen (1990), which allows us to formally address nonstationarity in model estimation. Table 4 reports the results for this estimation. 
Table 4. Fully-Modified Parameter Estimates.

\begin{tabular}{ccccc}
\hline & $\beta_{0}$ & $\beta_{1}$ & $\beta_{2}$ & $\beta_{3}$ \\
\hline Estimate & 22.3108 & 0.0485 & -0.1904 & -1.2993 \\
Standard Error & 2.5812 & 0.1161 & 0.0719 & 0.2155 \\
t-ratio & $8.6430^{* * *}$ & 0.4183 & $-2.6492^{* *}$ & $-6.0286^{* * *}$ \\
\hline
\end{tabular}

These results correspond to the estimation of the following model: $q_{t}=\beta_{0}+\beta_{1} p_{t}+\beta_{2} p s_{t}+\beta_{3} y_{t}$ by the Fully Modified single-equation technique of Phillips and Hansen (1990). $\left(^{* *}\right),\left({ }^{* *}\right),\left(^{*}\right)$ means significance at 1,5 and $10 \%$.

Notice that figures in Table 4 indicate the existence of complementarity instead of substitutability between wine and beer as well as a non significant effect of own-price over wine consumption. Nonetheless, results from the instability tests (Table 5 and 6) reveal that this relationship is not stable over time. The Hansen's $L_{c}$ test shows that the null of cointegration for (2.1) can not be rejected using 3\% critical values. Likewise, the SupF test, which is helpful in discovering whether a swift shift in regime in (2.1) is present, reveals that series appear to be cointegrated but this long-run relationship is unstable ( $\mathrm{p}$-value $<=0.01$ ) over time. However, the information provided by this test does not necessarily mean that there are two cointegrating regimes which shifted at a particular point in time (Hansen, 1992). The evidence of this test only suggests that wine consumption, price of wine, price of beer and per-capita GDP are cointegrated, but the logarithmic approximation used in (2.1) appears unstable or may be misspecified. Notwithstanding, results from regressing model (2.1) without taking the logarithm of the variables do not change the above conclusion ${ }^{9}$ , suggesting that the relationship in (2.1) is indeed unstable over time. Alternatively, the information provided by the Gregory and Hansen's residual-based test suggests the existence of one structural break, although estimated break points differ among models. This fact may well be due to finite sample bias, as pointed out by Gregory and Hansen (1996). However, the Bai and Perron's methodology ${ }^{10}$ confirms the existence of a structural break occurring in 1982. Notice how close this estimate is from the one

${ }^{9}$ The results from running model (2.1) with variables in levels are not reported here but are available upon the author's request.

${ }^{10}$ Estimation of break dates and parameters were conducted using the companion GAUSS algorithm of Bai and Perron (2001). 
obtained by Gregory and Hansen's test when the alternative is a cointegrating regime shift model $(\mathrm{C} / \mathrm{S}$ model). Hence, it appears that a regime shift in domestic wine demand has indeed occurred. However, we can not tell, based solely on these pieces of information, whether this regime shift is due to a change in consumer preferences or the occurrence of an exogenous intervention event. Notwithstanding, the estimated date of the break is consistent with the date at which some important events affected the Chilean wine industry. According to Mujica and Oncken (1984), the major crisis faced by the Chilean wine industry began in 1981 and may be attributed to the 80s' Chilean recession but also to the adoption of several market liberalization policies (such as changes in supervision and control of tax collection, changes in the tax structure and liberalization of wine production restrictions). Although most of these changes took place in 1979, several authors argue that the impacts of these policy changes were felt by the industry only three or four years after their adoption.

Table 5. Instability test results

\begin{tabular}{ccc}
\hline Tests & Statistic & p-value \\
\hline Lc test & 0.9214 & 0.0340 \\
MeanF test & 271.2026 & 0.0100 \\
SupF test & 908.0381 & 0.0100 \\
\hline
\end{tabular}

This table exhibits the results from the instability test of Hansen (1992).

Table 6. Residual-based tests.

\begin{tabular}{c|ccccc}
\hline Model & ADF & $\hat{\mathbf{t}}$ & $\mathbf{Z}_{\mathbf{t}}$ & $\mathbf{Z}_{\alpha}$ & $\hat{\mathbf{t}}$ \\
\hline Level shift (C) & -4.9784 & 1989 & $-5.0844^{*}$ & -36.4682 & 1989 \\
Level shift/trend (C/T) & $-5.6959^{* *}$ & 1990 & $-5.7621^{* *}$ & -41.003151 & 1990 \\
Regime shift (C/S) & -5.5404 & 1984 & -5.3194256 & -40.975469 & 1981 \\
\hline
\end{tabular}

This table exhibits the results from the residual-based test of Gregory and Hansen (1996). $(* * *),(* *),(*)$ means significance at 1,5 and $10 \%$.

Given the fact that evidence of one structural break was found, we estimate model (2.2) and obtain two different sets of elasticities, one for the 1949-1982 period and another one for the 1983-1998 period. This model is estimated by BP's technique (Bai and Perron, 1998) and by the FM single-equation technique of Phillips and Hansen (1990). Table 7 and 8 exhibits these results. 
Table 7. Two-regime model estimation results

\begin{tabular}{c|ccc|ccc}
\hline & \multicolumn{3}{|c|}{ Bai and Perron estimates } & \multicolumn{3}{c}{ Fully Modified estimates } \\
\hline Parameter & Estimates & Std Error & t-ratio & Estimates & Std Error & t-ratio \\
\hline$\beta_{0}$ & 6.6616 & 2.6205 & $2.5418^{* * *}$ & 8.7035 & 2.0902 & $4.1640^{* * *}$ \\
$\beta_{1}$ & -0.1318 & 0.0642 & $-2.0520^{* *}$ & -0.0762 & 0.0496 & $-1.5363^{*}$ \\
$\beta_{2}$ & -0.0187 & 0.0412 & -0.4545 & -0.0391 & 0.0319 & -1.2257 \\
$\beta_{3}$ & -0.1395 & 0.2008 & -0.6948 & -0.3041 & 0.1597 & $-1.9042^{* *}$ \\
$\beta_{4}$ & 27.7596 & 5.5152 & $5.0333^{* * *}$ & 16.6804 & 2.0902 & $7.9803^{* * *}$ \\
$\beta_{5}$ & -0.5023 & 0.2520 & $-1.9936^{* *}$ & -0.4035 & 0.2009 & $-2.0085^{* *}$ \\
$\beta_{6}$ & 1.5948 & 1.1412 & $1.3975^{*}$ & 1.1288 & 0.8823 & 1.2794 \\
$\beta_{7}$ & -2.0566 & 0.7055 & $-2.9151^{* * *}$ & -1.4203 & 0.5680 & $-2.5005^{* *}$ \\
\hline
\end{tabular}

This table shows the results from estimating the following two-regime model $q_{t}=\beta_{0}+\beta_{1} p_{t}+\beta_{2} p s_{t}+\beta_{3} y_{t}+\beta_{4} D U_{t}+\beta_{5} p_{t} D U_{t}+\beta_{6} p s_{t} D U_{t}+\beta_{7} y_{t} D U_{t}+v$;

$D U_{t}=1(t>1982)$ where 1 (.) is the indicator function.

$\left(*^{* *}\right),\left({ }^{*}\right),(*)$ means significance at 1,5 and $10 \%$.

Table 8. Domestic wine demand elasticities.

\begin{tabular}{c|cc|cc}
\hline & \multicolumn{2}{|c|}{ Bai and Perron estimates } & \multicolumn{2}{c}{ Fully Modified estimates } \\
\hline & $\mathbf{1 9 4 9 - 1 9 8 2}$ & $\mathbf{1 9 8 3 - 1 9 9 8}$ & $\mathbf{1 9 4 9 - 1 9 8 2}$ & $\mathbf{1 9 8 3 - 1 9 9 8}$ \\
\hline Own-price & $-0.1318^{* *}$ & $-0.6341^{* * *}$ & $-0.0762^{*}$ & $-0.4797^{* * *}$ \\
Cross-price & -0.0187 & $1.5761^{*}$ & -0.0391 & $1.0897^{*}$ \\
Income & -0.1395 & $-2.1961^{* * *}$ & $-0.3041^{* *}$ & $-1.7244^{* * *}$ \\
\hline
\end{tabular}

For the 1949-1982 period, elasticities correspond to the parameter estimates $\beta_{i}$, $\mathrm{i}=0, . ., 3$. . The 1983-1998 elasticities are obtained by adding to the corresponding parameter $\beta_{\mathrm{i}}$ the value of $\beta_{\mathrm{i}}, \mathrm{j}=4, \ldots, 7$.

Thus, the 1983-1998's own-price elasticity is equal to $\beta_{1}+\beta_{5}=-0.6341$. The remaining elasticities are computed likewise. $t$-ratios were computed as follows:

$$
t\left(\beta_{i}+\beta_{j}\right)=\frac{\left(\beta_{i}+\beta_{j}\right)}{\sqrt{\operatorname{Var}\left(\beta_{i}+\beta_{j}\right)}} .
$$

$\left({ }^{* *}\right),\left({ }^{* *}\right),\left({ }^{*}\right)$ means significance at 1,5 and $10 \%$.

As a first issue, notice the difference arising between the 1949-1982's and the 1983-1998's own-price elasticities. According to the figures in Table 7 and 8, the domestic wine demand becomes more price-elastic after the structural break has taken place, i.e., after 1982. This can be seen as the result of the introduction of new wine varieties in the domestic market during the last two decades. As already mentioned, liberalization policies and diminishing domestic wine consumption forced local winer- 
ies to internationalize their production. However, the varieties of wine being produced at that time were not of the taste of foreign consumers who demanded 'premium' wines instead of the 'traditional' wines being supplied to the domestic market. Consequently, many Chilean wine producers shifted from the production of 'traditional' wines to the production of premium wine varieties. Although in a first stage these premium wines were mainly produced to be commercialized in foreign markets, some of them began to be offered in the domestic market (Fuentes and Vargas, 2002). As a result of this, domestic market witnessed an 'expansion' in terms of wine varieties and wine quality spectrum available for domestic consumers. Thus, it is this broader availability of wine varieties which may have caused a change in domestic consumer preferences for wine. Following the preference approach suggested by the literature on differentiated products, the introduction of new varieties in a Chamberlinian framework will increase the price-elasticity of the aggregated demand since now a greater number of close substitutes is being offered to the market. Furthermore, the Perloff and Salop (1985) model suggests that the smaller the gap between the value of the most preferred good and the next one, the more elastic the demand for the good. In this sense, the introduction of more varieties of wine helps to reduce this gap and thus, to increase the price-elasticity of the domestic demand for wine.

An important fact is that of an increase of wine varieties with a reduction of per capita wine consumption during the 1983-1998 period. Using a product-characteristic approach to model domestic consumer preferences, we could argue that a market with smaller consumer expenditure can perfectly sustain more product variety. This is so because locational (or product characteristic) models make a distinction between the degree of dispersion of preferences (market width) and the density of consumer expenditure at each location of the product characteristic space (market depth). Thus, it is possible for a market to sustain more product variety even if consumer expenditure has fallen on condition that consumer preferences are more diverse and not necessarily greater in number. In the case being analyzed, this constitutes a very appealing approach for explaining the observed higher wine varieties in a context where market depth has been reducing.

In light of our previous discussion, the increase in wine varieties, 
which resulted from the deregulation process faced by the Chilean wine industry in the eighties, may have induced a change in domestic consumer preferences for wine through the alteration of product diversity available for domestic consumers ${ }^{11}$. This change in preferences is consistent with the higher price-elasticity found for the domestic wine demand for the 1983-1998 period.

A related issue worth being discussed is the role played by beer in the domestic demand for wine. For the 1949-1981 period, results in Tables 5 and 6 indicate that the estimated price of beer parameter does not statistically differ from zero ${ }^{12}$. Nonetheless, the 1983-1998's results point toward a substitution effect between wine and beer. This is in line with the observed increases of $60 \%$ in per capita beer consumption during the past two decades, and with the transformation of beer into the most important 'competitor' of wine in the domestic market for alcoholic beverages, mainly in the medium socioeconomic segment (Cruz, 1999; Ainzúa, 2003). Thus, the results on cross-price elasticity appear to support the claim that beer has become an important substitute of wine during the last two decades in Chile. Similar to the arguments presented in the preceding paragraph to explain the role of wine varieties, we may think of this result as supporting evidence for the claim that a modification in domestic consumer preferences for wine through product diversity has indeed occurred. Although a more definitive answer requires the estimation of a complete demand system for alcoholic beverages (in order to compute elasticities of substitution), we may conjecture that the increase in the varieties of alcoholic beverages has resulted in a more price-elastic domestic demand for wine, when the whole alcoholic beverage market is considered ${ }^{13}$.

Finally, the magnitude and significance of the income elasticity estimate deserve a more detailed discussion. Contrary to previous findings,

\footnotetext{
${ }^{11}$ For a survey on product variety models, see Lancaster (1990).

${ }^{12}$ The $t-r a t i o n$ for this parameter is equal to -0.4545 for the Bai and Perron estimates and -1.2257 for the Hansen's Fully-Modified estimates. Theses ratios are not significant at $10 \%$ of confidence level.

${ }^{13}$ The estimation of a complete demand system requires enough data to ensure reliable estimates. Available data in Chile are not enough for conducting a reliable time-series analysis of this demand system.
} 
income elasticity turned out to be negative for both the 'stable' relationship proposed in (2.1) and the two regime model in (2.2) (see Tables 4 and 7). In the first case, we find an income elasticity of -1.3 , whereas in the second case this estimate fluctuates between -0.14 and -0.30 (depending on the estimation technique employed) for the 1949-1982 period and between -1.72 and -2.20 for the 1983-1998 period. At a first sight, these results may appear surprising and even contradictory. However, similar to the case of the own price-elasticity, these results might just be reflecting the fact that Chilean wine consumers have become more demanding consumers in what regards wine quality but 'softer drinkers' in what regards wine quantity, as suggested for instance by Schnettler and Rivera (2003). To better understand this point, notice that aggregated wine consumption is mainly explained by low quality wine. However, the expansion in the domestic market has been lead by high quality wines, whereas consumption of low quality wines has declined over the last two decades (Ainzúa, 2003). In light of this, it is not surprising to find a negative income elasticity when wine consumption is taken in aggregated terms. Certainly, if data on wine consumption by types of wines were available to carry out a time-series analysis, we could observe a very different picture. Our conjecture is that a positive income elasticity might be found when premium wine consumption is considered in isolation.

\section{Conclusions and Final Remarks}

This paper investigates possible changes in domestic consumer preferences for Chilean wine through the estimation of a demand function that allows for structural breaks and regime shifts in the cointegrating relationship. For the estimation of the domestic wine demand we use time-series techniques that address the problems posed by nonstationarity in model variables. Our results indicate that demand parameters are unstable over time and that a regime shift in domestic wine demand exists. Consequently, we estimate a 'two regime' shift model and obtain two separates sets of elasticities. Two interesting results arise from the estimation of this two-regime model. First, domestic wine demand becomes more price-elastic after 1982, i.e., after the structural break in the domestic wine demand has taken place. Instead of attributing this 
particular result to an autonomous change in consumer preferences, we argue that the higher own-price elasticity is the consequence of the introduction of new wine varieties in the domestic market. Under a differentiated product approach to model the domestic consumer preferences, the introduction of new varieties causes the domestic wine demand to be more price elastic. Furthermore, this approach also allows us to explain how a market with smaller consumer expenditure can be consistent with more wine varieties. This is possible when consumer preferences are more diverse even if market depth is smaller. Thus, the increase in wine varieties (as a result of the deregulation suffered by the domestic wine industry) may be one of the reasons that explains the observed shift in the domestic wine demand as well as the higher price-elasticity for the 1983-1998 period.

A second issue that leads us to think of a change in domestic consumer preferences through a modification of product diversity, is the substitution effect between wine and beer found after 1982. This results is in line with the observed increase in per capita beer consumption and the decrease of per capita wine consumption in the last two decades in Chile. Hence, our findings on cross-price elasticity for the 1983-1998 period may be considered as supporting evidence for the claiming that beer has become one of the most important substitutes of wine in the domestic market for alcoholic beverages during the last two decades. Although a more definitive answer for this requires the estimation of a complete demand system for alcoholic beverages, we may conjecture that a broader number of alcoholic beverages available in the domestic market increases the price-elasticity of the domestic demand for wine. Certainly, this last issue constitutes an interesting avenue for further research.

\section{References}

Ainzúa, F. (2003), 'El competitivo negocio de las bebidas alcohólicas', Revista Logística y Distribución 22, 5-14.

Anderson, K., Norman, D. and Wittwer, G. (2002), Globalization of the World's Wine Markets, Discussion paper 3169, Centre for Economic Policy Research, London, UK. 
Bai, J. Perron, P. (1998), 'Estimating and Testing Linear Models with Multiple Structural Changes', Econometrica 66, 47-78.

Bai, J. Perron, P. (2001), Computation and Analysis of Multiple Structural Change Models, Working paper, Department of Economics, Boston University, USA.

Banda, R. 2002, 'Vinos. Profetas en su Tierra', Revista Publimark 161, 54-58.

CORFO (1998), Evolución y proyecciones de la producción vitivinícola. Technical Report. Corporación de Fomento a la Producción, CORFO, Chile. Available at http://www.corfo.cl/publicaciones/docs/anexo1.rtf.

Costa, V. (2001), La Vitivinicultura Mundial y la situación Chilena en 2001. Technical Report. Servicio Agrícola y Ganadero, S.A.G. Ministry of Agriculture, Chile. Available at http://www.sag.gob.cl.

Cremaschi, C. (1991), Análisis Comercial y Econométrico del Mercado Vitivinícola Chileno: un Enfoque Internacional, Unpublished manuscript, Facultad de Agronomía, Pontificia Universidad Católica de Chile, Chile. Cruz, M. (1999), 'Competencia: choque de cuerpos dorados', Revista Publimark 128, 6-10.

den Butter, F., Delifotis, A. Koning, R. (1997), Preference shifts in consumer demand for wine and beer, Series research memoranda 0052, Free University Amsterdam, Faculty of Economics, Business Administration and Econometrics, The Netherlands.

Engle, R. Granger, C. (1987), 'Co-integration and Error-Correction Representations, Estimation and Testing', Econometrica 55, 251-76.

Fuentes, P. Vargas, G. (2002), 'Vino Chileno: Crisis y Crecimiento', Revista Agronomia y Forestal UC 14, 15-19.

Gregory, A. Hansen, B. (1996), 'Residual-based tests for cointegration in models with regime shifts', Journal of Econometrics 70, 99-126.

Hansen, B. (1992), 'Tests for parameter instability in regressions with I(1) processes', Journal of Business \& Economic Statistics 10, 321-335.

Hendry, D. Juselius, K. (2000a), 'Explaining Cointegration Analysis: Part I', The Energy Journal 21, 1-42. 
Hendry, D. Juselius, K. (2000b), Explaining Cointegration Analysis: Part II, Discussion paper 00-20, Institute of Economics, University of Copenhagen, Denmark.

Lancaster, K. (1990), 'The Economics of Product Diversity: A Survey', Marketing Science 9, 189-206.

Lee, J. Strazicich, M. (2001), 'Break point estimation and spurious rejections with endogenous unit root tests', Oxford Bulletin of Economics \& Statistics 63, 535-558.

Lee, J. Strazicich, M. (1999), Minimum LM Unit Root Test with One Structural Breaks, Discussion paper 9932, Department of Economics, University of Central Florida, USA.

MacKinnon, J. (1996), 'Numerical Distribution Functions for Unit Root and Cointegration tests', Journal of Applied Econometrics 11, 601-18.

Martinez, J. (1995), Análisis de la evolución de las elasticidades de la demanda de vino, Unpublished manuscript, Departamento de Economía Agraria, Pontificia Universidad Católica de Chile, Chile.

Morales, A. Peruga, R. (2002), 'Purchasing Power Parity: Error Correction Models and Structural Breaks', Open Economies Review 13, 5-26.

Mujica, R. Celedon, C. (1982), Efecto tributario de la eliminación del IVA adicional a los alcoholes, Documento de trabajo nro.87, Instituto de Economía, Pontificia Universidad Católica de Chile, Chile.

Mujica, R. Oncken, H. (1984), 'Análisis Econométrico de la Industria Vitivinícola en Chile', Latin American Journal of Economics (Cuadernos de Economía) 21, 315-27.

Ng, S. Perron, P. (2001), 'Lag Length Selection and the Construction of Unit Root Tests with Good Size and Power', Econometrica 69, 1519-54.

Oncken, G. (1983), Un modelo económetrico de la industria vitivinícola: Una aplicación en el impuesto adicional al vino (1948-1981), Unpublished manuscript, Departamento de Economía Agraria, Pontificia Universidad Católica de Chile, Chile.

Pavez, D. (2002), Efectos de la posible alza del IVA adicional a los alcoholes sobre la industria vitivinícola, Unpublished manuscript, Facultad de Ciencias Económicas y Administrativas, Universidad de Chile, Chile. 
Perloff, J. Salop, S. (1985), 'Equilibrium with product differentiation', Review of Economic Studies 52, 107-120.

Phillips, P. (1986), 'Understanding Spurious Regressions in Econometrics', Journal of Econometrics 33, 311-40.

Phillips, P. (1995), 'Fully Modified Least Squares and Vector Autoregression’, Econometrica 63, 1023-1078.

Phillips, P. Hansen, B. (1990), 'Statistical Inference in Instrumental Variables Regressions with I(1) Processes', Review of Economic Studies 57, 99-125.

Schnettler, B. Rivera, A. (2003), 'Características del proceso de decisión de compra de vino en la IX Región de la Araucanía, Chile', Ciencias e Investigación Agraria 30, 1-14.

Vogelsang, T. Perron, P. (1998), 'Additional tests for a unit roots allowing for a break in the trend function at an unknown time', International Economic Review 39, 1073-1100.

Zivot, E., Andrews, D. (1992), 'Further evidence on the great crash, the oil price shock, and the unit root hypothesis', Journal of Business \& Economic Statistics 10, 251-270.

\section{Appendix 1: Data Source 1949-1998}

$\mathrm{q}_{\mathrm{t}}$ : Logarithm of per capita wine consumption. Total wine consumption is defined as the difference between total wine production minus total wine exports. Data on wine production and wine exports were obtained from the Servicio Agrícola y Ganadero, S.A.G., Department of Alcoholic Beverages, Ministry of Agriculture, Chile. Data on population were obtained from Instituto Nacional de Estadísticas, INE. (Chilean Bureau of Statistics).

$\mathrm{p}_{\mathrm{t}}, \mathrm{ps}_{\mathrm{t}}$ : Logarithm of real price of wine and real price of beer per liter, respectively. pt corresponds to the 'current price of wine' item, while pst is the price of beer item in the consumer price survey applied by the Instituto Nacional de Estadísticas, INE. (Chilean Bureau of Statistics). Both price series are deflated using the consumer price index published by the INE. 
$\mathrm{y}_{\mathrm{t}}$ : Logarithm of real per capita GDP. GDP series was obtained from different numbers of the Economic Bulletin published by the Central Bank of Chile. Data on total population was obtained from the Instituto Nacional de Estadísticas, INE. (Chilean Bureau of Statistics). This series has been deflacted using the implicit GDP deflactor published by the Central Bank of Chile.

Recebido em abril de 2004 e revisto em junho de 2004 